\title{
HAKIKAT PERCERAIAN (SEBUAH TINJAUAN FILOSOFIS TERHADAP MAKNA PERCERAIAN)
}

\author{
Ahmad Fauzi \\ UIN Sunan Gunung Jati Bandung \\ Email ; damhafauzi@gmail.com
}

\begin{abstract}
Perceraian merupakan suatu keadaan yang memerlukan pemahaman yang komperehensif, paradigma mengenai perceraian sangat berpengaruh terhadap posisi perceraian dan kehidupan masyrakat. Pemahaman mengenai perceraian sedikitnya harus dikaji dari 3 sudut pandang, yaitu yuridis, sosiologis dan filosofis. Sudut padang yuridis dianggap perlu sebagai suatu kepastian hukum, sementara kacamata sosiologis sebagai pembanding bagaimana manusia sebagai makhluk sosial memandang perceraian. disamping itu sudut pandang filosofispun tidak kalah penting, sebab memaknai esensi dari perkawinan dan perceraian tidak mungkin tanpa memakai kacamata filosofis.
\end{abstract}

Kata Kunci: hakikat perceraian, mitsaqon ghalidan, muasyaroh bilma'ruf, filosofis.

\begin{abstract}
Divorce is a situation that requires a comprehensive understanding, the paradigm of divorce is very influential on the position of divorce and public life. The understanding of divorce must be studied at least from 3 points of view, namely juridical, sociological and philosophical. The juridical point of view is considered necessary as a legal certainty, while the sociological perspective is a comparison of how humans as social beings view divorce. besides that, a philosophical point of view is no less important, because interpreting the essence of marriage and divorce is impossible without wearing a philosophical point of view.
\end{abstract}

Keywords: essence of divorce, mitsaqon ghalidan, muasyaroh bilma'ruf, philosophical. 


\section{A. Pendahuluan}

Pada dasarnya tujuan hukum perkawinan adalah menciptakan ikatan lahir bathin anatara seorang pria dengan seorang wanita sebagai suami isteri dengan tujuan membentuk keluarga (rumah tangga) yang bahagia dan kekal berdasarkan Ketuhanan Yang Maha Esa. ${ }^{1}$ Sedangakn tujuan perkawinan menurut Kompilasi Hukum Islam adalah untuk mewujudkan keluarga yang Sakinah, mawaddah dan rahmah. ${ }^{2}$

Akan tetapi setelah masuk dalam kehidupan rumah tangga, ada kalanya terjadi ketidaksesuaian antara suami-istri, yang bisa saja ketidaksesuaian yang tidak diinginkan itu tidak bisa diselesaikan, sehingga tidak dapat dipertahankan lagi dan berujung pada perceraian. Jika di dalam kehidupan suami isteri itu terjadi sesuatu yang dapat mengancam ketentraman tersebut dan kondisinya sudah sampai pada batas yang sulit terwujud kehidupan suami-isteri (yang harmonis), maka harus ada metode yang bisa digunakan oleh kedua belah pihak untuk berpisah satu sama lain.

Hakikat perceraian dianggap penting untuk dipahami oleh siapapun yang akan dan sedang, atau bahkan sudah menjalani masa pernikahan. Tentu saja hal ini dalam rangka menyampaikan esensi dari perceraian itu sendiri.

\section{B. Landasan Yuridis Perceraian}

Secara harfiyah talaq itu berasal dari kata Itlaq yang berarti melepaskan atau meninggalkan. ${ }^{3}$ Sedangkan menurut

1 Undang-undang Nomor 1 Tahun 1974 tentang Perkawinan

${ }^{2}$ Kompilasi Hukum Islam

3 A.W. Munawwir. Kamus Al-Munawwir, (Surabaya: Pustaka Progressif, 2002), edisi ke II, . 861. istilah adalah melepaskan tali perkawinan dan mengakhiri hubungan suami isteri. ${ }^{4}$

Hukum talak itu sendiri berbedabeda tergantung kepada kondisi masingmasing. Apabila terjadi perselisihan antara suami isteri dan tidak ada jalan penyelesaiannya, maka hukumnya adalah wajib. Apabila sang isteri telah melakukan sesuatu yang dapat mengotori kesuciannya, maka talak di situ hukumnya adalah sunah. Jika sang suami tidak menyukai isterinya dan isterinya tidak dapat menyenangkan suami, maka hukumnya jawaz (boleh). Sedangkan apabila si suami menjatuhkan hukum talak kepada isteri dalam keadaan haid atau dalam keadaan suci setelah digaulinya dan belum jelas apakah si isteri hamil atau tidak, maka hukum talaknya adalah haram. ${ }^{5}$

Landasan hukum thalaq dalam alquran dapat kita temukan dalam surat AtThalaq, diantaranya dalam Q.S at-Talaq ayat 1 :

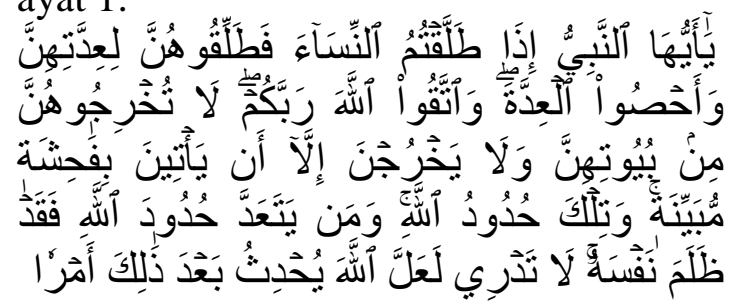

Artinya: "Hai Nabi, apabila kamu menceraikan isteri-isterimu maka hendaklah kamu ceraikan mereka pada waktu mereka dapat (menghadapi) iddahnya (yang wajar) dan hitunglah waktu iddah itu serta bertakwalah kepada Allah Tuhanmu. Janganlah kamu keluarkan mereka dari rumah mereka dan janganlah mereka (diizinkan) ke luar kecuali mereka mengerjakan perbuatan

4 Jaenal Aripin dan Azharudin Lathif. Filsafat Hukum Islam, (Jakarta: UIN Jakarta Press, 2006), cet. I, . 123.

${ }^{5}$ Rusli Hasbi. Rekonstruksi Hukum Islam: Kajian Kritis Sahabat Terhadap Ketetapan Rasulullah Saw, (Jakarta: Al-Irfan Publishing, 2009), cet. II, . 205. 
keji yang terang. Itulah hukum-hukum Allah dan barangsiapa yang melanggar hukum-hukum Allah, maka sesungguhnya dia telah berbuat zalim terhadap dirinya sendiri. Kamu tidak mengetahui barangkali Allah mengadakan sesudah itu sesuatu hal yang baru."

Perkawinan merupakan aspek hukum dan menyangkut perbuatan hukum, maka tentu saja tidak semua dan selamanya perkawinan itu dapat berlangsung secara langsung atau abadi. Tidak sedikit kenyataan terjadi di sekitar kita memperlihatkan contoh rapuhnya sendi-sendi suatu perkawinan yang tidak jarang berakibat pada timbulnya suatu perceraian dengan segala konsekuensinya dan aksesnya yang timbul. Karena perkawinan menyangkut perbuatan hukum maka dengan sendirinya dalam perceraian terkait pula perbuatan hukum, yang berarti bahwa ada suatu tantangan normatif yang terkait di dalam suatu perceraian. ${ }^{6}$

Di samping itu, landasan mengenai kebolehan perceraian ini juga ada salah satunya yang keluar sebagai sebuah hadits Rasulullah SAW:

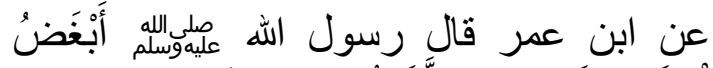

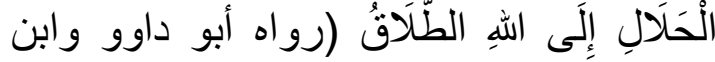

ماجه

"Dari Ibnu Umar. Ia berkata bahwa Rasulullah SAW, telah bersabda "sesuatu yang halal yang amat dibenci Allah ialah talak". (Riwayat Abu Daud dan Ibnu Majah). ",

Masalah putusnya perkawinan, Undang-Undang Nomor 1 Tahun 1974 mengaturnya dalam Bab VIII Pasal 38 sampai Pasal 41 Peraturan Menteri

${ }^{6}$ Abdurrahman Konoras, Telaah Tingginya Perceraian di Sulawesi Utara (Studi Kasus Putusan Pengadilan Agama. LPPM Bidang EkoSoBudkum, 1, 2014, . 55.

7 Rasjid, S. Fiqih Islam. Bandung: Sinar Baru Algensindo, 2011. .. 401-402.
Agama Nomor 3 Tahun 1975 Tahun 1975 Pasal 14 sampai dengan Pasal 36, dan hal-hal teknis lainnya dalam Peraturan Menteri Agama Nomor 3 Tahun 1975. Ketentuan Pasal 38 UU No 1 Tahun 1974 menyebutkan suatu perkawinan dapat putus karena tiga hal, yaitu kematian salah satu pihak, perceraian, dan atas putusan hakim. Selanjutnya dalam Pasal 39 ayat (1), (2) dan (3), disebutkan pula bahwa perceraian hanya dapat dilakukan di depan sidang Pengadilan setelah pengadilan (Majelis Hakim) tidak berhasil mendamaikan ke dua belah pihak, serta cukup alasan bagi mereka untuk bercerai karena tidak ada harapan lagi untuk hidup rukun dalam suatu rumah tangga, perkawinan mereka betulbetul sudah pecah. Gugatan perceraian dapat diajukan oleh pihak suami atau pihak istri dengan alasan yang telah ditentukan oleh peraturan perundangundangan yang berlaku. ${ }^{8}$

Undang-Undang Nomor 1 Tahun 1974 tentang Perkawinan merupakan sumber hukum perkawinan dan hukum keluarga Islam yang mengatur secara lengkap dan modern tentang perkawinan dan perceraian umat Islam yang berakar pada agama Islam. sebenarnya Undangundang ini jauh lebih sempurna dan lengkap mengenai substansi yang diatur di dalamnya, baik berupa asas-asas maupun norma-norma hukum perkawinan dan perceraian serta kehidupan berkeluarga. Akan tetapi, dalam realitas keberlakuannya dalam masyarakat Muslim sendiri di Islam Indonesia akhirakhir ini, sangat mudah terjadi perkawinan, demikian juga perceraian sehingga timbul kesan bahwa perkawinan itu bertujuan untuk cerai. Bahkan, pelanggaran Undang-undang perkawinan

${ }^{8}$ Tutik, T. Hukum Perdata dalam Sistem Hukum Nasional. Jakarta: Prenada Media Grup, 2008. .. 133. 
dalam bentuk perkawinan atau perceraian di bawah tangan yang lepas dari pengawasan dan pencatatan pejabat pencatat perkawinan dan perceraian. ${ }^{9}$

Undang-Undang Nomor 1 Tahun 1974 mengatur beberapa asas yang dapat berfungsi sebagai penghambat dan mengatur sedemikian rupa dalam pasalpasalnya guna mencegah terjadinya pelanggaran, baik terhadap asas-asas maupun terhadap norma-norma yang terjelma dalam rumusan pasal-pasal Undang-Undang Perkawinan. Asas-asas dimaksud antara lain, asas suka dibatasi dengan ketat, asas kematangan calon mempelai, asas perbaikan derajat kaum wanita, dan asas keharusan pencatatn perkawinan dan perceraian dengan ancaman hukuman bagi pelanggarnya, baik calon mempelai maupun pejabat pencatat perkawinan dan perceraian. ${ }^{10}$

\section{Landasan Sosiologis Perceraian}

Perceraian tidak dapat dipandang dari sudut pandang yuridis atau kepastian hukum saja, akan tetapi faktor sosiokultural berperngaruh besar terhadap paradigma masyarakat tentang perceraian. Bagaimana masyarakat menempatkan perceraian berdasarkan kacamata sosiologis, sebab menempatkan perceraian sebagai sebuah kegagalan adalah bias. ${ }^{11}$

Dalam persepektif sosiologis, perkawinan merupakan suatu proses pertukaran hak dan kewajiban yang terjadi diantara sepasang suami istri. oleh karena itu, perkawinan merupakan proses integrasi antara dua individu, maka proses pertukaran ini harus senantiasa dirudingkan dan dinegosiasikan.

9 Muhammad, A. K. Hukum Perdata Indonesia. Bandung: Citra Aditya Bakti, 2010, ... 68.

${ }^{10}$ Muhammad, A.K , ibid., h. 68-69.

11 Ramadani Wahyu S, Pengantar Studi Sosiologi Keluarga, Bandung: t.p, 2000, ... 152.
Kemudian, disadari ataupun tidak seringkali bahkan mayoritas perceraian terjadi disebabkan kegagalan pemenuhan hak dan kewajiban antar individu tersebut.

Banyak factor yang mempernagruhi tingginya angka perceraian, Sebagian sosiolog menganggap bahwa perceraian merupakan produk dari industrialisasi dan urbanisasi. ${ }^{12}$ Dintara indikasi perubahan sosial yang cukup besar prngaruhnya terhadap perceraian adalah:

1. Perubahan pada makna yang terkandung dalam perceraian, seiring berjalannya waktu makna perceraian yang sebelumnya dianggap tabu kini berangsur menjadi sesuatu yang biasa dan lumrah terjadi.

2. Perubahan pada longgarnya pengawasan kerabat, teman dan lingkungan tetangga terhadap kebutuhan keluarga, perubahan pola hubungan di masyarakat sebagai akibat dari industrialisasi dan globalisasi yang cenderung mengaraha kepada sikap apatis menyebabkan kemungkinan perceraian semakin tinggi.

3. Tersedianya berbagai piliahan di luar keluarga, ketergantungan antara suami istri merupakan salah satu sebab hubungan perkawinan berjalan langgeng, sementara akibat perubahan sosial dimana segala sesuatu bahkan dapat dengan mudah ditemukan diluar keluarga menyebabkan kecenderungan satu sama lain berkurang.

12 Sacanzoni, Letha dawson dan John Scanzoni, Men, Women and change: A Socilogy of Marriage and Family, New York: McGraw, Hill Book Company, 1961. 
4. Lahirnya tuntutan persamaan hak laki-laki dan perempuan, mulai menggeliatnya usaha-usaha untuk mendobrak bias gender nampaknya sedikit banyaknya mengusik doktrin patriarki yang sudah lama melekat di benak masyarakat, sehingga mereka yang tidak menerima paham ini lebih memilih mengakhiri pernikahannya. $^{13}$

Jika di atas sedikit saya uraikan mengenai factor-faktor yang berpengaruh terhadap tingginya angka perceraian, kemudian saya akan uraikan mengenai sebab-sebab perceraian berdasarkan survey yang dilakukan George Levinger ${ }^{14}$ pada tahun 1966 menyevuutkan 12 alasan keluarga yang mengajukan permohonan cerai, yaitu:

1. Pasangan senantiasa mengabaikan tugas-tugasnya terhadap rumah tangga dan anak;

2. Minimnya pendapat keluarga yang bewujud pada masalah keuangan;

3. Terjadinya pernyikasaan fisik terhadap pasangannya;

4. Tidak menghargai pasangannya dengan cara berteriak dan berkata kasar yang menyebabkan sakit hati bagi yang lainnya;

5. Tidak memiliki kesetiaan terhadap pasangannya;

6. Tidak puas melakukan hubungan seksual dengan pasangannya disebabkan oleh keengganan melakukan

\footnotetext{
${ }^{13}$ Ramdani Wahyu S,...157-159.

${ }^{14}$ George Levinger, Phisical abuse among applicant for divorce, dikutif dari Source of MAritasl Among Aplicants for Divorce, Amerikan Journal of Orthopsychitary 36, 1966.
}

hubungan suami istri dan tidak meberi kepuasan.

7. Meminum minuman yang memabukan;

8. Sering cemburu dan curiga terhadap pasangannya;

9. Kurang berkomunikasi dengan pasangan karena ketiadaan cinta dan perhatian satu sama lain;

10. Muncul intervensi dari pihak luar (kerabat) masing-masing pasangan.

11. Tuntutan yang berlebihan yang mengakibatkan masing-masing tidak sabar;

12. Perbuatan-perbuatan lain selain yang disebutkan di atas.

Survey yang dilakukan George Levinger tahun 1966 diatas nampaknya masih sangat relevan denga napa yang menjadi penyebab perceraian dewasa ini, sebab poin-poin di atas adalah poin yang sangat dasar dalam pembentukan keluarga.

\section{Landasan Filosofis Perceraian}

Berbicara mengenai perceraian maka tidak cukup melihat dari kacamata yuridis dan sosiologis, sebab perlu sebuah pemahaman mengenai hakikat/esensi perceraian itu sendiri.

Secara filosofis pernikahan merupakan sebuah upaya untuk mendapatkan dan berbagi kebagiaan lahir dan batin. Perwujudan kebahagiaan ini tentu saja harus menjadi motivasi dalam melaksanakan segala hak dan kewajiban yang timbul dari adanya ikatan perkawinan. Dalam rangka mewujudkan cita-cita pernikahan itu maka setiap individu harus betul-betul memahami makna mitsaqon ghalidan, muasyaroh bil'ma'ruf, dan Sakinah, mawadah juga rahmah.

Konsep perkawinan sebagai suatu ikatan yang kuat atau mitsaqon ghalidan 
merupakan wajah perkawinan yang ideal, sebagaimana tercantum dalam al-Qur'an surat al-Nisa ayat 21:

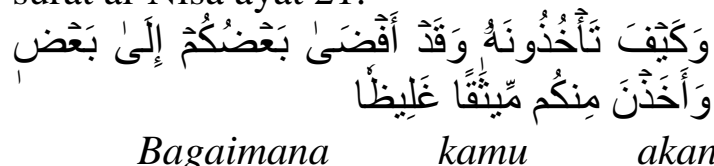
mengambilnya kembali, padahal sebagian kamu telah bergaul (bercampur) dengan yang lain sebagai suami-isteri. Dan mereka (isteri-isterimu) telah mengambil dari kamu perjanjian yang kuat. (Q.S Al-Nisa: 21).

Imam at-Thabari dalam Tafsir Thabari miliknya menukil pendapat Abu Ja'far yang menafsirkan ayat tersebut sebagai berikut:

قال أبو جعفر: وأولى هذه الأقوال بتأويل ذلك،

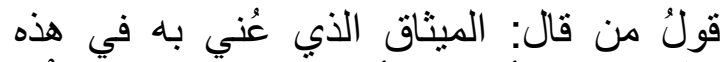

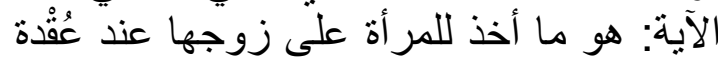

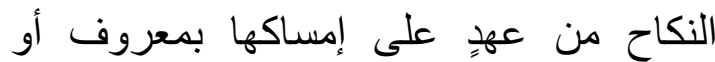
تسريحها بإحسان، فأقرّ به الرجل الرجل. لأن اله جل

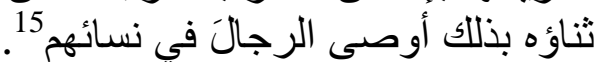

Abu Ja'far berkata: pendapat-pendapat di atas dalam menafsirkan mitsaq ghalidz yg paling baik adalah yaitu pendapat yang mengatakan bahwa maksud dari mitsaq ghalidz dalam ayat tersebut adalah suatu janji yang diberikan oleh calon suami untuk calon istri ketika akad nikah berupa janji akan menjaganya dengan baik (imsak bi ma'ruf) atau melepaskannya dengan baik juga (tasrih biihsan), karena Allah telah mewasiatkan hal itu (janji) kepada laki-laki untuk istrinya.

Dengan demikian, jika merujuk pada pendapat tersebut bahwasanya mitasqon ghalidzan merupakan dasar hubungan dalam perkawinan, yang mana secara garis besar perwujudannya merupakan tanggung jawab yang menjadi

\footnotetext{
${ }^{15} \mathrm{https} / /$ quran.ksu.edu.sa/tafseer/tabary/sur a4-aya21.html (Diakses tanggal 17 desember 2020 pukul 10.30 WIB)
}

kewajiban seorang suami, sebab secara tidak langsung segala kewajiban dan tanggung jawab yang semula berada di pundak wali kini berpindah kepada dirinya.

Akan tetapi, dalam menjalankan perkawinan sebagai suatu ikatan yang mitasqon ghalidzan minimalnya perlu melaksanakan muasyaroh bilma'ruf sebagaimana diamanatkan Q.S al-Nisa ayat 19 .

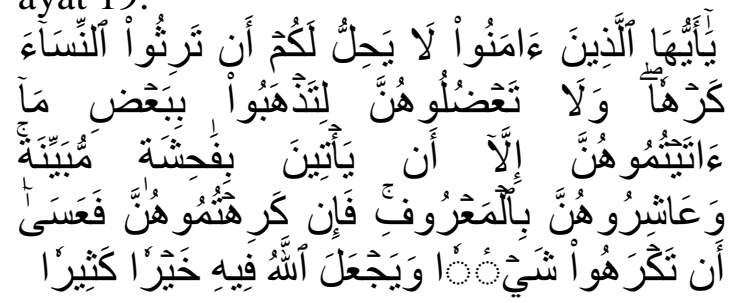

Hai orang-orang yang beriman, tidak halal bagi kamu mempusakai wanita dengan jalan paksa dan janganlah kamu menyusahkan mereka karena hendak mengambil kembali sebagian dari apa yang telah kamu berikan kepadanya, terkecuali bila mereka melakukan pekerjaan keji yang nyata. Dan bergaullah dengan mereka secara patut. Kemudian bila kamu tidak menyukai mereka, (maka bersabarlah) karena mungkin kamu tidak menyukai sesuatu, padahal Allah menjadikan padanya kebaikan yang banyak. (Q.S al-Nisa: 19)

Ibnu katsir dalam menafsirkan frasa wa'asyiruhunna bilma'ruf sebagai berikut:

Bertutur sapa dengan baiklah kalian kepada mereka, dan berlakulah dengan baik dalam semua perbuatan dan penampilan kalian terhadap mereka dalam batas yang sesuai dengan kemampuan kalian. Sebagaimana kalian pun menyukai hal tersebut dari mereka, maka lakukan 
olehmu hal yang semisal terhadap mereka. $^{16}$

Jika melihat pada pendapat Ibnu

Katsir diatas, lagi-lagi tanggung jawab lebih ditekankan kepada laki-laki, hal ini mengindkasikan bahwa memang disadari atau tidak bahwa laki-laki seringkali merasa "superior" dengan kedudukannya dalam rumah tangga. Secara filosofis bahwa perbutan baik dan segala kebaikan merupakan perlakuan yang ideal dalam hubungan sesama makhluk, sehingga hal ini bisa menjadi tolak ukur keberhasilan perkawinan dalam rangka menciptakan keluarga sakinah, mawaddah dan rahmah.

Alissa Wahid salah satu tokoh Gerakan perempuan di Indonesia pada suatu kesempatan mengatakan bahwa perspektif ini berbicara soal bagaimana berperilaku baik yang ternyata menjadi salah satu pilar dalam sebuah keluarga. Salah satunya adalah dengan saling memperlakukan dengan baik. "Perintahnya di dalam Al-Quran adalah wa'asyiruuhunna bil ma'ruf. Artinya perlakukanlah istrimu dengan ma'ruf. Ma'ruf itu artinya bukan semata boleh atau tidak boleh, tapi layak atau tidak layak, patut atau tidak patut, bermartabat atau menjaga martabat orang lain,",17

Berbagai ayat dan hadits, kemudian pendapat ulama terdahulu kaitannya dalam hukum keluarga ini kemudian diformulasikan dalam bentuk Kompilasi Hukum Islam sebagai produk fiqhnya Indonesia.

Kompilasi Hukum Islam misalnya dalam BAB XII tentang Hak dan Kewajiban Suami Istri pada pasal 77 ayat (1) dan (2). Menyebutkan:

\footnotetext{
${ }^{16}$ http://www.ibnukatsironline.com/2015/05 /tafsir-surat-nisa-ayat-19-22.html (Diakses tanggal 17 desember 2020 pukul 11.03 WIB)

17 https://uninus.ac.id/lima-pilar-bangunankeluarga-maslahah-menurut-alissa-wahid/ (Diakses tanggal 17 desember 2020 pukul 11.16 WIB)
}

(1) Suami isteri memikul kewjiban yang luhur untuk menegakkan rumah tangga yang sakinah, mawaddah dan rahmah yang menjadi sendi dasar dan susunan masyarakat;

(2) Suami isteri wajib saling cinta mencintai, hormat menghormati, setia dan memberi bantuan lahir bathin yang satu kepada yang lain;

Pasal yang tertulis dalam KHI diatas merupakan landasan filosofis dalam rangka menjalankan kewajiban sebagai suami istri, bahwa pemenuhan hak dan kewajiban harus berdasarkan cinta dan kasih saying, yang merupakan cita-cita luhur dari filsafat itu sendiri. Bahkan, seperti yang telah dijelaskan di awal, bahwa tujuan hukum perkawinan adalah menciptakan ikatan lahir bathin anatara seorang pria dengan seorang wanita sebagai suami isteri dengan tujuan membentuk keluarga (rumah tangga) yang Bahagia dan kekal berdasarkan Ketuhanan Yang Maha Esa. ${ }^{18}$ Sedangakn tujuan perkawinan menurut Kompilasi Hukum Islam adalah untuk mewujudkan keluarga yang Sakinah, mawaddah dan rahmah. ${ }^{19}$

Sehingga secara filosofis perceraian merupakan suatu keadaan yang sangat dihindari sebab bertentangan dengan tujuan perkawinan itu sendiri, penafsiran ini bukan hanya atas aturan perundang-undangan yang berlaku. Akan tetapi jika merujuk pada salah satu hadits Nabi Muhammad Saw yang dikutip diatas, yang artinya: "Dari Ibnu Umar. Ia berkata bahwa Rasulullah SAW, telah bersabda "sesuatu yang halal yang amat dibenci Allah ialah talak”. (Riwayat Abu

\footnotetext{
18 Undang-undang Nomor 1 Tahun 1974 tentang Perkawinan

${ }^{19}$ Kompilasi Hukum Islam
} 
Daud dan Ibnu Majah). Sangat jelas dalam hadits ini, pada dasarnya perceraian merupakan suatu keadaan yang Allah sangat tidak senangi, sehingga baik berdasarkan undang-undang maupun hadits yang memaknainya dari kacamata filosofis, sekali lagi perceraian adalah suatu keadaan yang seharusnya bisa dihindari selama para pihak mampu memaknai konsep hak dan kewajiban secara utuh.

\section{E. Penutup}

Tujuan perkawinan untuk meciptakan ikatan keluarga yang harmonis, dalaam bingkai keluarga Sakinah seringkali tidak dapat terwujud, dan perceraian merupakan pilihan akhir yang tidak dapat dielakan. Banyak faktor yang mempengaruhi berubahnya paradigma masyarakat terhadap perceraian yang berimplikasi juga terhadap tingginya angka perceraian itu sendiri.

\section{DAFTAR PUSTAKA}

A.W. Munawwir. Kamus Al-Munawwir, Surabaya: Pustaka Progressif, 2002, edisi ke II.

Abdurrahman Konoras, Telaah Tingginya Perceraian di Sulawesi Utara (Studi Kasus Putusan Pengadilan Agama. LPPM Bidang EkoSoBudkum, 2014.

George Levinger, Phisical abuse among applicant for divorce, dikutif dari Source of Maital Among Aplicants for Divorce, Amerikan Journal of Orthopsychitary 36, 1966.

Jaenal Aripin dan Azharudin Lathif. Filsafat Hukum Islam, Jakarta: UIN Jakarta Press, 2006, cet. I.
Kompilasi Hukum Islam.

Muhammad, A. K. Hukum Perdata Indonesia. Bandung: Citra Aditya Bakti, 2010.

Ramdani Wahyu S, Pengantar Studi Sosiologi Keluarga, Bandung, t.p, 2010.

Rasjid, S. Fiqih Islam. Bandung: Sinar Baru Algensindo, 2011.

Rusli Hasbi. Rekonstruksi Hukum Islam: Kajian Kritis Sahabat Terhadap Ketetapan Rasulullah Saw, Jakarta: Al-Irfan Publishing, 2009 , cet. II.

Sacanzoni, Letha dawson dan John Scanzoni, Men, Women and change: A Socilogy of Marriage and Family, New York: McGraw, Hill Book Company, 1961.

Tutik, T. Hukum Perdata dalam Sistem Hukum Nasional. Jakarta: Prenada Media Grup, 2008.

Undang-undang Nomor 1 Tahun 1974 tentang Perkawinan.

Website:

https://quran.ksu.edu.sa/tafseer/tabary/sur a4-aya21.html (Diakses tanggal 17 desember 2020 pukul 10.30 WIB)

http://www.ibnukatsironline.com/2015/05 /tafsir-surat-nisa-ayat-19-22.html (Diakses tanggal 17 desember 2020 pukul 11.03 WIB)

https://uninus.ac.id/lima-pilar-bangunankeluarga-maslahah-menurutalissa-wahid/ (Diakses tanggal 17 desember 2020 pukul 11.16 WIB) 